\title{
Correlation of Outpatient Waiting Time with Patient's Satisfaction and Loyalty at Private Hospital
}

\author{
Fransisca Stefanie ${ }^{1}$, Ratna Indrawati $\mathrm{L}^{2}$ \\ Magister Manajemen, Universitas Esa Unggul Jakarta, Indonesia ${ }^{1,2}$
}

\begin{abstract}
A huge chance is happening in the hospital's advancement globally and competitively. Which means pharmacy care at the hospital also becomes inseparable from health care system provided by the hospital. From the patient's point of view, the long and exhausting queue could lead to dissatisfaction that could also lead to the loss to the hospital itself as less and less patients would consider coming in the future. The purpose of this research is to find the correlation between outpatient waiting time with patient's satisfaction and patient's loyalty. This research's design is cross sectional and was conducted on the SEM (Structural Equation Model) PLS (Partial Least Square) data analysis method. The data was taken from the questionnaire on June 2018, with 60 persons' who were waiting the pharmacy were asked to complete the questionnaire, which then be analyzed by SEM PLS method. The service waiting time (responsiveness) significantly affects the patient's satisfaction but not significantly on the patient's loyalty. Patient's satisfaction significantly affects the loyalty.
\end{abstract}

Keywords: Pharmacy Waiting Time, Patient's Satisfaction, Patient's Loyalty

\section{INTRODUCTION}

These days, a huge chance is happening in the hospital's advancement globally and competitively. The increasingly number of hospital in Indonesia, both the state owned and private ones, requires the hospital to provide the care, professionalism and competence that reflects the best healthcare quality (Adelina, 2016). The pharmacy services at the hospital is inseparable from the hospital's healthcare system, which hygely contributes to the hospital's revenue (revenue center) which could reach more than $50 \%$ of the revenue (Septini, 2012). Pharmacy service is included in the main service at the hospital, due to almost all the services provided at the hospital are related to the pharmacy. But today, most hospitals in Indonesia haven't performed the pharmacy services as expected, due to some obstacles such as the personnel's skills, lack of management knowledge, imperfect management policy and the related department's limited knowledge on the pharmacy services.

For the patient who is having the long waiting time during the pharmacy service, this will lead to dissatisfaction, that in the long term will cause loss for the hospital, preventing the same patient to go back to the same hospital in the future. The patient will also tell his or her dissatisfaction and experience to the other people which then will lower the people's trust to the hospital's pharmacy and later on generate disobedience to the information provided by the hospital's pharmacy (Erhun, 2005).

As one of the biggest hospitals in Indonesia caring so many patients, research still found that this hospital is still facing the same problem involving the speed of service response which is still behind the expected target. At the beginning, the researcher interviewed 10 patients who were waiting to be served at the the hospital outpatient pharmacy. Researcher began with several questions about the waiting time, starting from when the prescription was handed to the pharmacist until the moment when the medicine was received back by the patient. According to hospital's standard, the maximum waiting time is 15 minutes for ready-made medicine and 30 minutes for individually prepared medicine. The result is 6 out of 10 persons complained about how extremely long they had to wait to get their medicine from the pharmacy. which, for instance, those 6 patients mentioned that they finally got their medicine after 30 minutes and even more. But for the rest four patients, they mentioned that they are very satisfied and quite satisfied with the service. On the average, the four patients got their medicine served after 15 minutes of waiting. The researcher also interviewed two pharmacist working at the outpatient pharmacy unit, both of them also confirmed that the patient's waiting time is still way behind the target as standardized by the hospital.

The purpose of this research is to find the correlation between outpatient waiting time with patient's satisfaction and patient's loyalty.This study will discuss the waiting time specificity (responsiveness) that is issued with patient 


\title{
International Advanced Research Journal in Science, Engineering and Technology
}

\author{
Vol. 5, Issue 10, October 2018
}

satisfaction and loyalty. Data will be taken from a questionnaire distributed to patients who are waiting for medication at the hospital pharmacy. In this study, patients will be patient and patient with patient satisfaction and patient loyalty. In contrast to previous research by Insani (2017) which discusses the dimensions of service quality. This research was also carried out using questionnaires and surveys with AMOZ 18, this research was a cross sectional study, and analyzed using SEM PLS. Then Helni (2015) is descriptive in nature to determine the level of patient satisfaction with various services performed in various fields. This research was also conducted on type B hospitals that have received accreditation from the JCI (Joint Commission International), and ACHS (Australian Council on Healthcare Standards).

\section{LITERATURE REVIEW}

Service Quality: According to Fitzsimmons (2011) in Sulastiyono (2011) explained that the service quality is something complex where rating the service quality through five principles, the measurements, such as: reliability, the ability to provide the correct and exact types of service as promised to the customers; responsiveness, the awareness to act fast to help the customers and provide on time service; assurance, the knowledge politeness and self confidence of the employees, the dimension of assurance reflects: the competence to provide the service, being polite and respectful to the customers; empathy, providing individual care to the customers. The dimension of empathy reflect willingness to approach and provide protection and try to understand the customer's needs and feeling; tangible, something which is real, such as: the appearance of employees, othe facilities i.e the supporting equipment or devices.

Medicine Serving Waiting Time: Camacho (2006) conceptualized the waiting time as the time measurement that has been used by the patients in accesing health care. The patients have invested a lot to access the healthcare services which is commonly called as the willingness to wait for the services. How long patients wait could really affect the satisfaction rate, that if this thing is not carefully taken care, it will lower the patient's satisfaction rate, and eventually the patients will not show any loyalty which possibly to move to another healthcare provider. Serving time is started since patient hands over the prescription to the pharmacist, until the patient receives the medicine and leaves the pharmacy (Kepmenkes RI, 2008). The waiting time is devided into two categories, ready-made medicine, and individually prepared medicine. Ready-made medicine is started since the patient hands over the prescription until the patient receives the ready made, and the same for individually medicine, only this time is until the patient receives the individually made medicine.

Standard od Pharmacy Service at The Hospital

\begin{tabular}{|l|l|l|}
\hline No & Service Standard & Standard Value \\
\hline 1. & Service waiting time & \\
\hline & a. Ready-made medicine & $\leq 30$ menit \\
\hline & b. Individually prepared medicine & $\leq 60$ menit \\
\hline 2. & No error medicine & $100 \%$ \\
\hline 3. & Patient's satisfaction & $\geq 80 \%$ \\
\hline 4. & Formularium based prescriptions & $100 \%$ \\
\hline
\end{tabular}

Source: Permenkes No 58 tahun 2014

Patient's Satisfaction: According to Kotler and Keller (2003), customer's satisfaction is the customer's feeling, wether it's the 'satisfied' feeling or 'dissatisfied' feeling that comes from comparing a product with the hope of the customer on the product. The product's quality that doesn't fit the reality will certainly make the customer feel dissatisfied, on the other hand if the product meets the customer's expectation, the customer will certainly show satisfaction. According to Budiastuti (2002) in Nooria (2008), the factors affecting the patient's satisfaction are: quality of product, the patients will be satisfied if their evaluation shows that the product or service being used is qualified. Patient's perception on the product or service quality is affected by two factors which are the product's quality or service and how communicative the company is, in this case the hospital in promoting itself; service quality, patient will be satisfied if he or her gets the proper service or suitable as expected; emotional factor, patient will be proud, satisfied, amazed with the hospital that looks expensive; price, the more expensive the healthcare service, the more hopes the patient has. On the other hand, the same quality hospital but with cheaper price, will give a higher value to the patient; cost, the patient who doesn't need to spend extra money and time to get the service, then the patient will tend to get satisfied with the service.

Customer Loyalty: According to Griffin (2003), is the customer who has been repeatedly buying a product or using a service from the same company still using the product or service even there is another product or service offered by another company. According to Hidayat (2009), consumer's loyalty is commitment odf a consumer upon the marked based on the positive response an reflected in the consistent repeated order. The indicators of this consumer's loyalty are: trust, is the positive response of the consumer upon the market; emotion commitment is a physiological 


\title{
International Advanced Research Journal in Science, Engineering and Technology
}

\author{
Vol. 5, Issue 10, October 2018
}

commintment upon the market; switching cost is the consumer's response on the extra cost that occurs due to the switching process from one provider to another provider; word of mouth, the publicity behavior of a consumer upon the market; cooperation, the consumer's behavior that shows that he or she can work together with the market.

\section{HYPOTHESIS DEVELOPMENT}

Waiting time is the time needed starting from the oment the patients hands over the prescription to outpatient pharmacy until the patient gets the medicine and leaves the pharmacy (Kepmenkes RI, 2008). Good service is related to the customer's satisfaction, which means the hospital must be able to control the serving time to reach the patient's satisfaction. Nowadays, lots of hospital apply the pharmacy service policy that is simpler than the standard to fulfill the patient's satisfaction.Even the actual waiting time hasn't exceeded the standard, it could be culprit of the patient's dissatisfaction and tend to make the patient to get the medicine from another pharmacy, and lesser the objective dimension coverage which is the actual waiting time. For the patient that experiences long waiting time, this will probably cause a dissatisfaction, creating looses to the hospital in the long term i.e lower down the probability of the same patient to go back to the same hospital in the future. The patient will also start telling his or her dissatisfaction to other people, that will also lower down the competitive healthcare system and patient's trust to the pharmacy, that in the nextstep will create the patient's disobedience to the information, by the pharmacy (Afolabi and Erhun, 2005).

\section{H1: There is correlation between service waiting time and the patient's satisfaction}

According to Hidayat (2009), the consumer;s loyalty is consumer's commitment on the market based on the positive respons and reflected in trust, is the positive response of the consumer upon the market; emotion commitment is a physiological commintment upon the market; switching cost is the consumer's response on the extra cost that occurs due to the switching process from one provider to another provider; word of mouth, the publicity behavior of a consumer upon the market'; cooperation, the consumer's behavior that shows that he or she can work together with the market. Manifestation and the continuation of the consumer in using the healthcare facilities which was provided by the company and to keep being the consumer of that company. Loyalty is the proof of consumer who always becomes the customer who holds the strong power and positive behavior on that company (Griffin, 2003).

\section{H2: There is correlation between service waiting time and patient's loyalty}

Consumer's loyalty doesn't occur directly on the first time encounter but it will occur after repeatedly accesing the healthcare service at the hospital. And of course, this is the thing which is expected from every hospital to be able to survive (Ayubi, 2008). Consumer's loyalty is a manifestation and continuation of consumer's satisfaction in using the healthcare services provided by the company and to keep being the consumer of that company. Having a satisfied customer is not enough, but he or she should be very satisfied since satisfaction will being loyalty (Bowen and Chen 2001). Having reached the customer's satisfaction means a company will get the loyalty from its customer. The company could get lots of profits from the customer's loyalty, if the satisfaction is high, when the loyalty will also be so high (Lovelock and Wright, 2005). If the satisfaction has been reached, the company will be able to maintain the old customer's satisfaction, automatically have a good image upon the product and start felling his or her experience to other people.

H3: There is correlation between patient's satisfaction and patient's loyalty

\section{RESEARCH METHOD}

This research is categorized as the quantitative research. The approach used in this research is cross sectional, and SEM method is used to analyze and find out the significance level and alsothe linkage between the variable. Minimun samples as Hair, et al. (2008) are taken where the total of the questionnaire items are multiplied by five. This research is using 10 questions and involving 60 respondents. On this research, there is one exigent which is the waiting time (X), endogent variable which is the patient's satisfaction (Y1) and the patient's loyalty (Y2). To measure the waiting time, four responsiveness indicators from SERVQUAL Parasuraman et all (1988) are used. For satisfaction, three indicators (Crosby et all, 1990 and Kom and Cha, 2002) are used. And for the loyalty, three indicators from Lin and Ding (2006) are used.

\section{RESULT}

Validity test is done by analyzing the Kaiser Meyer-Olkin (KMO) dan Anti Image where the value has to be more than 0.5 . The value of KMO below 0.5 means the analysis can't be acceoted and for each questionaire's validity is done using the Anti Image Matrix test. The result of all indicators shows the value aboce 0.5 thus the factors are accepted. The reability test is using the Cronbach' Alpha method. It is done by calculating the coefficient Alpha $(\alpha)$ assisted by the statistic software. If the value is more than 0.6 or close to 1 , it means that the research instrument is said to be 


\title{
International Advanced Research Journal in Science, Engineering and Technology
}

\author{
Vol. 5, Issue 10, October 2018
}

reliable. On this reliability test, the result shows the Alpha Cronbach is more than 0.6 thus the waiting time indicators, satisfaction and loyalty are considered reliable. Next step is the data processing using the SEM with the PLS approach. Convergent reliability of the measurement model is scored bassed on the correlation between the item score or component score and construct score, calculated with PLS. Individual reflective measurement is considered high if it correlates with more than 0.7 of the construct that wats to be measured. For initial research of the development, the measurement scale of 0.5-0.6 is considered enough. The outer loading result, is shown as follow:

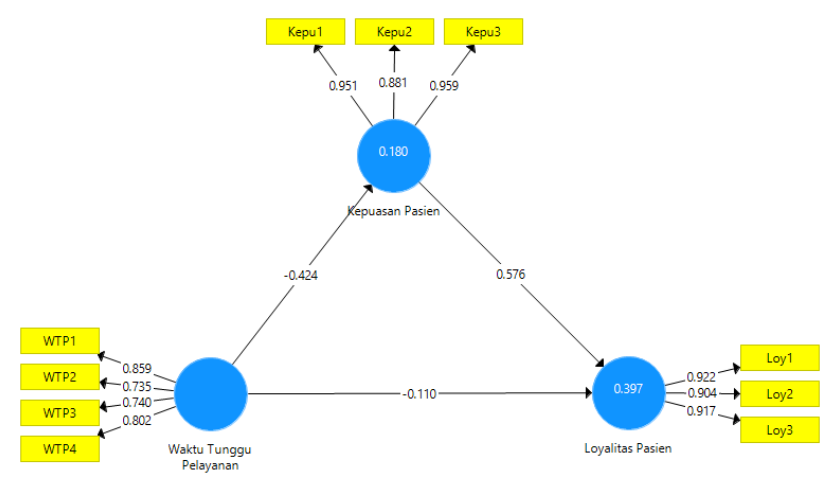

Source.: SmartPLS

Figure 1 Measurement Model

Based on the outer loading shown above, the results already meet the convergent validity since all the loading factors are minimum more than 0.5 . This research shows the correlation between the variables that have the higher values compared to the other construct indicators and vice versa. This shows that the latent construct indicator is better than the others. Another test is to determine the validity of the construct by examining the Average Variance Extracted (AVE) value, with the AVE value should be more than 0.5. The composite reliability output for all the variables above shows more than 0.70 , conducting that the reliability is good. The test on the structural model is done by examining the R-square of Goodness-fit-model test, as shown below.

It is known that the responsiveness variable could explain the patient's satisfaction as much as $18 \%$. The waiting time and patient's satisfaction variables could explain the $39,7 \%$ of loyalty variable. The rest can be explained by the other factors which are not included in the model.

The second test is to observe the effect significance by examining the parameter coefficient value and t-statistic significance value.

Table 1: Relation and Result

\begin{tabular}{|l|l|l|l|}
\hline Hypothesis & Statement of the Hypotheses & T-value & Description \\
\hline H1 & $\begin{array}{l}\text { There is effect of service waiting } \\
\text { time on the patient's satisfaction }\end{array}$ & 4,250 & The data support the hypothesis \\
\hline H2 & $\begin{array}{l}\text { There is effect of waiting time on } \\
\text { the patient's loyalty }\end{array}$ & 0,826 & $\begin{array}{l}\text { The data do not support the } \\
\text { hypothesis }\end{array}$ \\
\hline H3 & $\begin{array}{l}\text { There is effect of the patient's } \\
\text { satisfaction on the patient's loyalty }\end{array}$ & 6,952 & The data support the hypothesis \\
\hline
\end{tabular}

\section{DISCUSSION}

In the first test result (H1), it was found that the results of the analysis supported the H1 hypothesis, namely the Waiting Time for Drug Services Affecting Patient Satisfaction. This is consistent with the research of Herjunianto, et al. (2014) conducted a descriptive study. The methods used are observation, ghost shopping, interviews, and price surveys and customers. The results of this study indicate that the estimated length of waiting, even though it has not actually exceeded SPM, is at the root of the problem of patient dissatisfaction and encourages taking drugs outside the hospital, thereby reducing the scope of the objective dimension, namely actual waiting time, pharmaceutical services. Insani (2017) conducted a research with observational analysis method using cross sectional method. Data released using PLS with Smart PLS Program. The results show that the quality of pharmaceutical services has a significant impact on patient satisfaction. This result is also in accordance with the theory proposed by Camacho (2006) conceptualizing waiting time as a measure of time that has been used by patients in accessing a health service. Patients invest their time to access a form of health service which is often referred to as a willingness to wait for service. The length of waiting time can affect the value of the patient's head to the health service, so that if the waiting time is not noticed and left unchecked, it will reduce the patient's satisfaction with the service he receives. 


\title{
International Advanced Research Journal in Science, Engineering and Technology
}

\author{
Vol. 5, Issue 10, October 2018
}

The second test results (H2), it was found that the results of the analysis did not support the hypothesis $\mathrm{H} 2$, that there was no effect of waiting time for drug services on patient loyalty. Based on the results of the above research shows the same results on research conducted by Insani (2017) conducted a study with observational analysis method using cross sectional method. Data dianalsia also uses PLS with Smart PLS Program. The results show that service quality does not have a significant impact on patient loyalty.In accordance with Adelina, et al. (2016) made a study of the relationship between service quality and patient loyalty with analytical survey method with cross sectional approach. Data analysis uses univariate and bivariate. The results show that there is no relationship between waiting time and patient loyalty. From the results of the above research, it can be shown that the components that influence loyalty in the hospital are not only measured by the waiting time of the pharmacy services. Although the drug service was felt for a long time, the patient continued to go back to treatment and take medicine at this hospital. This can be caused by other resources, such as qualified doctors, drugs that are given to be appropriate, the prices given are reasonable, nurses' services are satisfying so that the loyalty of patients seeking treatment is created. Patient loyalty will be formed by itself if the hospital is able to improve the quality of the services it provides, not only in terms of waiting time for drug services. So that long-term relationships between patients and hospitals will be formed.

In the third test results (H3), it was found that the results of the analysis supported the H3 hypothesis of patient satisfaction affecting patient loyalty. This is consistent with the research conducted by Msallam (2015). The results prove that there is a significant relationship between customer satisfaction and customer loyalty. Customers will be more loyal when they are satisfied. In waiting times can be better understood and on satisfaction while waiting (Pruyn and Smidts, 1998), meaning that if the company increases the satisfaction of waiting time (waiting time satisfaction) for consumers it can be ascertained that customer loyalty will increase. Likewise, vice versa if the satisfaction of waiting time (satisfaction waiting time) decreases, automatically customer loyalty will decrease so in this case the waiting time satisfaction (waiting time satisfaction) causes customer loyalty. So the satisfaction of waiting time affects customer loyalty. Some facts in previous research studies that consumers give an assessment of the time while waiting for a negative impact on customer satisfaction. Law, et al. (2004) focused on the effect of waiting time and service size in repurchase behavior and customer satisfaction, these results contained differences in waiting times and appreciated satisfaction while waiting so that it affected consumer satisfaction and the frequency of repurchase would depend on when the customer visited. This means that when consumers do not experience satisfaction in service it will automatically reduce consumer loyalty for the company in the future, then if service satisfaction increases, consumer loyalty will increase. So that service satisfaction affects loyalty.

\section{MANAGERIAL IMPLICATION}

In order to shorten the pharmacy witing time, thus a review with the lean management method must be conducted, where we can see which process takes the logest time and reduces the speed of the service. The existing process must be made streamline, which shows efficiency that will occur if the in the process, no bottleneck is found on one or more points of process and no pending activity also found along the process chain.

Since the data input is still performed manually, therefore it could be switched to the automatic presicription input system, so for every patient that has gone through the doctor's examination, the medicine in formation will be put into the interconnected system. When the doctor finishes putting the prescription into the system and press click, the prescreibed medicine will automatically show up on pharmacy's screen, which will then be processed by the pharmacist, so when the patient arrives at pharmacy, he or she just needs to pay for the medicine and take it.

Another way to reduce waiting time is using robotic pharmacy. The robotic pharmacy uses the pill-pick system to separate batches of pills into individual doses. The collected pills are bagged and stored. Pill-pick is a modular system with connected devices that automatically produce unit dose medicaments. The automated warehouse, where the dose medicaments are stored, is always ready to provide personalised therapy to patients. The physicians send orders to the system electronically. The robotic system then picks the packages and dispenses the individual doses of pills. The system dispenses more than 10,000 doses per day. The packed doses of the pills required by a patient are tied together on a plastic ring and barcoded. The nurses confirm the right medication for the patients through the bar code readers. The system also keeps record of the medication stock available in the pharmacy.

\section{CONCLUSION}

Waiting time aould give a negative impact abd si significant to the patient's satisfaction when the waiting time increases, thus the satisfaction will drop. This research shows waiting time and satisfaction will also increase the patient's loyalty. From the research, we an find a significant impact or effect between satisfaction and loyalty. When the satisfaction increasesloyalty will also increase. Patient's satisfaction could become the bridge between waiting time and the loyalty. 


\title{
International Advanced Research Journal in Science, Engineering and Technology
}

\author{
Vol. 5, Issue 10, October 2018
}

\section{SUGGESTION}

This research is still very limited to the impact of responsiveness to the satisfaction and loyalty of a patient. Trough the patient's satisfaction as the intervening variable, therefore in order to improve this research it is suggested that next research will also include other variables such as assurance, empathy, reliability, and tangible. The next research is also expected to take more samples into the process. This research can also provide information that can be analyzed using methods such as polynomial regression. Research time that can be used for more samples and data. The research place is also not available at the hospital, other companies that are not patients can also be used, and find other than type B hospital.

\section{REFERENCES}

[1]. Afolabi \& Erhun, 2003. Patients' response to waiting time in an out-patient pharmacy in Nigeria. Tropical Journal of Pharmaceutical Research, December 2003; 2 (2): 207-214

[2]. Adelina, .F, Najmah, Ainy .A. Hubungan Kualitas Pelayanan Dengan Loyalitas Pasien Di Instalasi Rawat Jalan Rumah Sakit Khusus Mata Provinsi Sumatra Selatan. 2016

[3]. Budiastuti. 2002. Faktor-faktor dalam meningkatkan kepuasan pasien di rumah sakit

[4]. Bowen, John T \& Chen, SL (2001). The Relationship Between Customer Loyalty dan Customer Satisfaction, International Journal of Contemporary Hospitality Management, Vol. 13 N0 5, pp 213-217

[5]. Camacho F, Anderson R, Safrit A. The relationship between patient's perceived waiting time and office-based practice satisfaction. 2006.

[6]. Crosby, Lawrence A., Kenneth R. Evans, and Deborah Cowles (1990), "Relationship quality in services selling: An Interpersonal Influence perspective," Journal of Marketing

[7]. Fitzsimmons, J. A. \& Fitzsimmons, M. J.: Service Management - Operations, Strategy, Information Technology; McGraw - Hill, 2011

[8]. Griffin, Jill. 2003. Customer Loyality: How to earn it, How to keep it. USA: A Division of Simon and Schukers Inc

[9]. Helni 2015. Tingkat Kepuasan Pasien Terhadap Pelayanan Apotek Di Kota Jambi.

[10]. Hidayat, Rachmad. 2009. Pengaruh Kualitas Layanan, Kualitas Produk dan Nilai Nasabah Terhadap Kepuasan dan Loyalitas Nasabah Bank Mandiri. Jurnal Manajemen dan Kewirausahaan

[11]. Hair, J.F. Ringle, C.M \& Sarstedt, M. (2011) PLS-SEM: indeed a silver bullet. Journal of Marketing Theory and Practice, vol. 19, no. 2 (spring 2011), pp. 139-151

[12]. Herjunianto, Viera .W, Prihastuty .J. Faktor yang Mempengaruhi Cakupan Layanan Farmasi di Instalasi Rawat Jalan Rumah Sakit.2014

[13]. Kepmenkes RI, 2008, Standar Pelayanan Minimal Rumah Sakit Nomor 129/Menkes/SK/II/2008

[14]. Kim, W. G., \& Cha, Y. (2002). Antecedents and consequences of relationship quality in hotel industry, International Journal of Hospitality Management, Vol. 21, pp. 321-38.

[15]. Law, K. S., Wong, C., \& Song, L. J. (2004). The construct and criterion validity of emotional intelligence and its potential utility for management studies. Journal of Applied Psychology, 89, 483-496

[16]. Lin, C. P. \& Ding, C. G. (2006). Evaluating group difference in gender during the formation of relationship quality and loyalty in ISP service. Journal of organizational and end user computing

[17]. Lovelock, Christopher dan Wright, Lauren. 2005. Manajemen Pemasaran Jasa. Jakarta: PT. Indeks Kelompok Gramedia

[18]. Kotler \& Keller, Kevin L. 2007, Manajemen Pemasaran ( Jilid 1 ), Cetakan Kedua, Indeks, Jakarta

[19]. Msallam (2015). The Relationship between Customer Satisfaction and Customer Loyalty in the Banking Sector in Syria. Journal of Marketing and Consumer Research

[20]. Nooria, Widoningsih. 2008. Pengaruh Persepsi Kualitas Jasa Pelayanan Terhadap Kepuasan dan Loyalitas Pelanggan di RSU Saras Husada Purworejo. Surakarta

[21]. Parasuraman, A., Zeithaml, V. A., \& Berry, L. L. (1988). SERVQUAL : A Multiple-Item Scale for Measuring Consumer Perception of Service Quality. Journal of Retailing

[22]. Peraturan Mentri Kesehatan Republin Indonesia Nomor 56 Tahun 2014 Tentang Klasifikasi dan Perizinan Rumah Sakit

[23]. Peraturan Menteri Kesehatan Republik Indonesia No. 72 Tahun 2016 Tentang Standar Pelayanan Kefarmasian di Rumah Sakit

[24]. Pruyn, A., \& Smidts, A. (1998). Effects of waiting on satisfaction with the service: Beyond objective time measurements. International Journal of Research in Marketing, 15, 321-334

[25]. Septa Dwi Insani, Lukman Hakim, Kurnia Widyaningrum. The Effect of Outpatient Pharmaceutical Service Quality on Patient Loyalty Through Patient Satisfaction of Karsa Husada General Hospital Batu 2017. Journal of Applied Management (JAM)

[26]. Septini, Renni. 2011. "Analisis Waktu Tunggu Pelayanan Resep Pasien Askes Rawat Jalan Di Yanmasum Farmasi RSPAD Gatot Soebroto tahun 2011”. Depok: Universitas Indonesia 